\title{
Importance of perinatal versus horizontal transmission of hepatitis B virus infection in China
}

\author{
G B Yao
}

\begin{abstract}
China has one of the highest rates of hepatitis $B$ virus (HBV) endemicity in the world. In a survey of five provinces, the overall HBV infection rate in the general population was found to be $42 \cdot 6 \%$, with $10 \cdot 3 \%$ testing positive for hepatitis $B$ surface antigen (HBsAg). Higher rates were found in rural than in urban areas. The prevalence of HBsAg among children under 1 year of age is quite low but increases rapidly thereafter, reaching a peak among 5 to 9 year olds. The pattern of age distribution suggests that horizontal transmission is an important route of $\mathrm{HBV}$ infection during early childhood, and the proportion of chronic HBsAg carriage attributable to perinatal transmission has been estimated at only 13-20\%. Contact with infected family members probably accounts for much of the horizontal transmission in children. In a nationwide survey, $27 \cdot 2 \%$ of families were found to have one or more HBsAg positive members and a strong tendency for family clustering has been identified. The strategy for prevention of HBV infection includes vaccination of all newborns, whether their mothers are HBsAg positive or negative, together with vaccination of high risk populations, and improved control measures in clinics and blood transfusion centres.
\end{abstract}

(Gut 1996; 38 (suppl 2): S39-S42)

Keywords: hepatitis B, China, perinatal transmission, horizontal transmission, vaccination.

China has one of the highest rates of hepatitis $B$ virus (HBV) endemicity in the world, with an estimated 150 million hepatitis B surface antigen (HBsAg) carriers nationwide. Most chronic carriers of HBsAg are infected during early childhood, emphasising the importance of both perinatal and horizontal transmission. Assessment of the routes of HBV transmission is essential for the establishment of an appropriate strategy for prevention and vaccination.

Jingan Clinical Immunology Research Centre, Jingan Qu Central Hospital, Shanghai, China G B Yao

Correspondence to: Professor G Yao, Shanghai Jingan Qu Central Hospital, Clingan Qu Central Immunology Clinical Immunology Kang Road, Shanghai, China 200040.
Prevalence of HBV infection in China

The reported prevalence of $\mathrm{HBV}$ infection and HBsAg carrier rates vary according to the particular population samples and ethnic groups studied, and the detection methods used. In a survey carried out in 1979, a total of 277186 subjects (138360 males and 138826 females), sampled from 209 counties and cities in 29

provinces, municipalities, and autonomous regions, were investigated using the RPHA method. ${ }^{1}$ The overall standardised prevalence of $\mathrm{HBsAg}$ positivity was reported to be $8 \cdot 8 \%$ (range $3 \cdot 8 \%$ to $16 \cdot 8 \%$ ), with a higher rate in rural $(10 \cdot 2 \%)$ than in urban $(7 \cdot 9 \%)$ areas. As the RPHA method is comparatively insensitive, a further study was carried out using RIA. $^{2}$ A total of 4039 serum samples taken from subjects in five provinces were investigated. The overall HBV infection rate was found to be $42 \cdot 6 \%$ (range $35 \cdot 5-61 \cdot 6 \%$ ), with an HBsAg carrier rate of $10.3 \%$ (range $7 \cdot 4-15 \cdot 4 \%)^{2}$ Between 1984 and 1987, another seroepidemiological study of hepatitis B was carried out in four provinces. ${ }^{3}$ In total, 10484 serum samples were collected and tested by RIA. Positivity rates for HBsAg and for any $\mathrm{HBV}$ marker were $10 \cdot 1 \%$ and $58 \cdot 2 \%$, respectively (Table I) ${ }^{3}$ The highest carrier rate was found among children under 3 years of age, and the highest annual increase in $\mathrm{HBsAg}$ positivity also occurred in this age group. Two peaks of HBsAg positivity were recorded, in children aged 2 to 8 years and adults aged 35 to 40 years. The average positivity rate for antiHBs antibodies was $32.2 \%$ and increased with age as a result of the combined impact of both perinatal and horizontal transmission. The lowest ratio of $\mathrm{HBsAg}$ to anti-HBs positivity was seen in children aged 3 years or less, who were therefore at the highest risk of infection and of becoming chronic carriers.

Perinatal versus horizontal transmission According to a nationwide epidemiological survey in 1979 to 1980 , the prevalence of HBsAg carriage among children under 1 year of age is comparatively low (3.2\%). From 1 to 4 years of age, however, it increases rapidly to $8.9 \%$, reaching of $>10 \%$ among 5 to 9 year olds. ${ }^{1}$ Similar results were shown in another study during 1984 to $1987 .{ }^{3}$ This pattern of age distribution suggests that horizontal transmission is an important route of $\mathrm{HBV}$ infection during early childhood. The relative importance of horizontal and perinatal transmission has been investigated in a study carried out in four provinces. ${ }^{4}$ The study population comprised 4500 children and mothers, all of whom

were tested for HBsAg positivity. The results showed that children born to HBsAg positive mothers ran a significantly higher risk of becoming $\mathrm{HBsAg}$ positive themselves than those born to HBsAg negative mothers, with a relative risk ratio (RR) of 5.3 (Table II). This could be attributed to the combined effects of 
TABLE I HBV prevalence in inhabitants of four provinces ${ }^{3}$

\begin{tabular}{|c|c|c|c|c|c|c|}
\hline $\begin{array}{l}\text { Age } \\
\text { (y) }\end{array}$ & $\begin{array}{l}\text { Number } \\
\text { tested }\end{array}$ & $\begin{array}{l}H B s A g+v e \\
n(\%)\end{array}$ & $\begin{array}{l}\text { Anti-HBs+ve } \\
n(\%)\end{array}$ & $\begin{array}{l}\text { Anti-HBc+ve } \\
n(\%)\end{array}$ & $\begin{array}{l}H B V+v e \\
n(\%)\end{array}$ & $\begin{array}{l}H B s A g: \\
\text { anti-HBs ratio }\end{array}$ \\
\hline $\begin{array}{c}0- \\
1- \\
2- \\
3- \\
4- \\
5- \\
6- \\
7- \\
8- \\
9- \\
10- \\
15- \\
20- \\
25- \\
30- \\
35- \\
40- \\
45- \\
50- \\
60-\end{array}$ & $\begin{array}{r}131 \\
229 \\
256 \\
286 \\
262 \\
244 \\
266 \\
285 \\
238 \\
231 \\
1289 \\
1113 \\
898 \\
887 \\
972 \\
672 \\
507 \\
131 \\
730 \\
557\end{array}$ & $\begin{aligned} & 5(3 \cdot 8) \\
& 20(8 \cdot 7) \\
& 32(12 \cdot 5) \\
& 31(10 \cdot 8) \\
& 32(12 \cdot 2) \\
& 28(11 \cdot 5) \\
& 25(9 \cdot 4) \\
& 36(12 \cdot 6) \\
& 26(10 \cdot 9) \\
& 22(9 \cdot 5) \\
& 127(9 \cdot 9) \\
& 126(11 \cdot 3) \\
& 73(8 \cdot 1) \\
& 91(10 \cdot 3) \\
& 102(10 \cdot 5) \\
& 85(12 \cdot 7) \\
& 65(12 \cdot 8) \\
& 48(11 \cdot 1) \\
& 67(9 \cdot 2) \\
& 34(6 \cdot 1)\end{aligned}$ & $\begin{array}{r}8(6 \cdot 1) \\
22(9 \cdot 6) \\
23(9 \cdot 0) \\
27(9 \cdot 4) \\
42(16 \cdot 0) \\
49(20 \cdot 1) \\
52(19 \cdot 6) \\
75(26 \cdot 3) \\
65(27 \cdot 3) \\
74(32 \cdot 0) \\
422(32 \cdot 7) \\
399(35 \cdot 9) \\
302(33 \cdot 6) \\
310(34 \cdot 9) \\
323(33 \cdot 2) \\
242(36 \cdot 0) \\
195(38 \cdot 5) \\
192(44 \cdot 6) \\
279(38 \cdot 2) \\
201(36 \cdot 1)\end{array}$ & $\begin{array}{r}15(11 \cdot 5) \\
37(16 \cdot 2) \\
52(20 \cdot 3) \\
57(19 \cdot 9) \\
72(17 \cdot 5) \\
80(32 \cdot 6) \\
74(27 \cdot 8) \\
109(38 \cdot 3) \\
111(46 \cdot 6) \\
98(42 \cdot 4) \\
554(42 \cdot 9) \\
555(49 \cdot 9) \\
400(44 \cdot 5) \\
412(46 \cdot 5) \\
455(46 \cdot 8) \\
365(54 \cdot 3) \\
278(54 \cdot 8) \\
243(56 \cdot 4) \\
393(53.8) \\
321(57.6)\end{array}$ & $\begin{array}{r}20(15 \cdot 3) \\
50(21 \cdot 8) \\
70(27 \cdot 3) \\
80(28 \cdot 0) \\
91(34 \cdot 7) \\
97(39 \cdot 8) \\
104(39 \cdot 1) \\
147(51 \cdot 6) \\
130(54 \cdot 6) \\
128(55 \cdot 4) \\
725(56 \cdot 3) \\
698(62 \cdot 7) \\
524(58 \cdot 4) \\
565(63 \cdot 7) \\
590(60 \cdot 7) \\
457(68 \cdot 0) \\
364(71 \cdot 8) \\
316(73 \cdot 3) \\
502(68 \cdot 8) \\
383(68 \cdot 8)\end{array}$ & $\begin{array}{l}1: 1 \cdot 6 \\
1: 1 \cdot 1 \\
1: 0 \cdot 7 \\
1: 0 \cdot 9 \\
1: 1 \cdot 3 \\
1: 1 \cdot 8 \\
1: 2 \cdot 1 \\
1: 2 \cdot 1 \\
1: 2 \cdot 5 \\
1: 3 \cdot 4 \\
1: 3 \cdot 3 \\
1: 3 \cdot 2 \\
1: 4 \cdot 1 \\
1: 3 \cdot 4 \\
1: 3 \cdot 2 \\
1: 2 \cdot 8 \\
1: 3 \cdot 0 \\
1: 4 \cdot 0 \\
1: 4 \cdot 2 \\
1: 5 \cdot 9\end{array}$ \\
\hline Total & 10484 & $1076(10 \cdot 3)$ & $3302(31 \cdot 5)$ & $4681(44 \cdot 7)$ & $6041(57 \cdot 6)$ & $1: 3 \cdot 1$ \\
\hline \multicolumn{2}{|c|}{ Adjusted rate $(\%)^{\star}$} & $10 \cdot 1$ & $32 \cdot 2$ & $45 \cdot 5$ & $58 \cdot 2$ & $1: 3 \cdot 2$ \\
\hline
\end{tabular}

^Prevalence adjusted according to baseline age structure estimated in 1982 from national census statistics. horizontal and perinatal transmission. It was estimated that the proportion of chronic HBsAg carriage attributable to perinatal transmission ranged from only $13 \%$ to $19 \cdot 6 \% .{ }^{45}$ Furthermore, HBsAg carrier children of HBsAg positive mothers accounted for only $32.3 \%$ of the entire carrier population. Horizontal transmission therefore seems to outweigh perinatal transmission as a risk for $\mathrm{HBV}$ infection in China. Attempts to prevent perinatal transmission of the virus should thus be combined with simultaneous strategies to prevent horizontal transmission.

\section{Possible mechanisms of horizontal transmission}

According to the study described earlier, at least $80 \%$ of chronic carriers of $\mathrm{HBsAg}$ are infected via horizontal transmission, with most being infected during early childhood. ${ }^{4}$ Close contact with infected family members, particularly the mother, is probably the major source of infection. Other important routes of infection in children include close contact with other HBsAg positive infants and injections with inadequately sterilised syringes. In young adults, medical procedures such as injections, dental treatments, surgery, and acupuncture may be important routes of $\mathrm{HBV}$ transmission. Sexual contact with infected spouses and blood transfusions are other possible sources.

TABLE II Prevalence of $H B s A g$ among children born to $H B s A g$ positive or negative mothers ${ }^{4}$

\begin{tabular}{|c|c|c|c|c|c|c|}
\hline \multirow[b]{2}{*}{ Region } & \multirow[b]{2}{*}{$\begin{array}{l}\text { Age } \\
(y)\end{array}$} & \multicolumn{2}{|c|}{ Born to $\mathrm{HBs} \mathrm{Ag}-$ ve mothers } & \multicolumn{3}{|c|}{ Born to $H B s A g+v e$ mothers } \\
\hline & & $\begin{array}{l}\text { Number } \\
\text { tested }\end{array}$ & $\begin{array}{l}H B s A g+v e \\
n(\%)\end{array}$ & $\begin{array}{l}\text { Number } \\
\text { tested }\end{array}$ & $\begin{array}{l}H B s A g+v e \\
n(\%)\end{array}$ & $R R$ \\
\hline Shanghai & $\begin{array}{r}0- \\
10- \\
>20\end{array}$ & $\begin{array}{r}186 \\
89 \\
472\end{array}$ & $\begin{array}{c}10(5 \cdot 4) \\
3(3 \cdot 4) \\
51(10 \cdot 8)\end{array}$ & $\begin{array}{l}23 \\
25 \\
39\end{array}$ & $\begin{array}{r}5(21 \cdot 7) \\
9(36 \cdot 0) \\
20(51 \cdot 3)\end{array}$ & $\begin{array}{r}4 \cdot 0 \\
10 \cdot 7 \\
4 \cdot 8\end{array}$ \\
\hline Hebei & $\begin{array}{r}1- \\
10- \\
>20\end{array}$ & $\begin{array}{l}478 \\
694 \\
353\end{array}$ & $\begin{array}{l}49(10 \cdot 1) \\
35(5 \cdot 0) \\
16(4 \cdot 5)\end{array}$ & $\begin{array}{l}49 \\
53 \\
24\end{array}$ & $\begin{array}{r}17(34 \cdot 7) \\
12(22 \cdot 6) \\
6(25 \cdot 0)\end{array}$ & $\begin{array}{l}3 \cdot 4 \\
4 \cdot 5 \\
5 \cdot 5\end{array}$ \\
\hline Heilong-jiang & $\begin{array}{l}0- \\
7-18\end{array}$ & $\begin{array}{l}489 \\
982\end{array}$ & $\begin{array}{l}24(4 \cdot 9) \\
58(5 \cdot 1)\end{array}$ & $\begin{array}{l}44 \\
91\end{array}$ & $\begin{array}{l}18(40.9) \\
35(38.5)\end{array}$ & $\begin{array}{l}8 \cdot 3 \\
6 \cdot 5\end{array}$ \\
\hline Sichuan & $3-5$ & 371 & $37(9 \cdot 8)$ & 38 & $19(50 \cdot 0)$ & $5 \cdot 0$ \\
\hline
\end{tabular}

$\mathrm{X}_{\mathrm{M}-\mathrm{H}}=320 \cdot 9, \mathrm{RR}_{\mathrm{M}-\mathrm{H}}=5 \cdot 3, \mathrm{X}_{\mathrm{M}-\mathrm{H}}=\mathrm{X}_{\text {Mantel-Haenszal }}\left(\chi^{2}\right.$ test $)$.
At present, neither homosexual activity nor intravenous drug abuse are responsible for $\mathrm{HBV}$ infection in China, but careful monitoring is advisable. The most likely routes of transmission are discussed in more detail below.

\section{INTRAFAMILIAL TRANSMISSION}

In a nationwide survey, 19421 families were investigated, $5305(27 \cdot 2 \%)$ of which were found to have one or more $\mathrm{HBsAg}$ positive members. ${ }^{6}$ Analysis of the intrafamilial distribution of HBsAg using a binomial model suggested a strong tendency for family clustering. ${ }^{6}$ The overall family clustering rate of $\mathrm{HBsAg}$ in China was found to be $37 \%$, with a higher rate in rural $(37.8 \%)$ than in urban $(33.6 \%)$ areas. ${ }^{6}$ The clustering rate was also found to be directly proportional to the general prevalence of $\mathrm{HBsAg}$ positivity in most provinces. Within families, the HBsAg carrier rate in children was closely related to their parents' HBsAg status, particularly in rural areas (Tables III and IV).

\section{TRANSMISSION IN NURSERY AND}

KINDERGARTEN

HBV infection may be transmitted through close contact between carriers and noninfected children in nurseries and kindergartens. A report from Sichuan Province of 1167 children attending a seven day kindergarten during the period 1985 to 1986 indicated an HBV marker prevalence of $41.3 \%$ and an $\mathrm{HBsAg}$ positivity rate of $12.7 \%$. After one year of follow up, the annual $\mathrm{HBV}$ infection rate among 448 susceptible children was found to be $13 \%$, with $3.8 \%$ remaining $\mathrm{HBsAg}$ positive. The number of newly infected children was directly correlated to the number of HBsAg carriers present in each classes $(p<0 \cdot 05) .{ }^{7}$

TRANSMISSION VIA INADEQUATELY STERILISED SYRINGES AND ACUPUNCTURE NEEDLES

An investigation into the relation between HBV infection and disinfection of needles and syringes was carried out in a six year study in a village in Hebei Province. ${ }^{8}$ This village, with 4000 inhabitants, has two small poorly equipped outpatient clinics where five private practitioners work. The investigators found that hypodermic needles were being changed between patients but not the syringes. During the period 1984 to 1986 , positivity rates for HBV markers and HBsAg were $39.4 \%$ and $20.9 \%$, respectively, in 1 year olds and $36.9 \%$ and $11.6 \%$ in 2 year olds. Besides mother to infant transmission, this high prevalence of HBV infection may also be attributed to frequent vaccinations and therapeutic injections using unsterilised syringes during early childhood. Between 1987 and 1990, stricter measures were taken to prevent $\mathrm{HBV}$ infection in these clinics, including training of medical personnel, provision of sterilised syringes, needles and transfusion sets, and the use of sterilised syringes and needles for single injections. After the introduction of these measures, 
TABLE III Relation between HBsAg status of parents and that of their children ${ }^{6}$

\begin{tabular}{|c|c|c|c|c|}
\hline $\begin{array}{l}\text { HBs } A g \text { status } \\
\text { of parent }\end{array}$ & $\begin{array}{l}\text { No of } \\
\text { children } \\
\text { tested }\end{array}$ & $\begin{array}{l}\text { Children } \\
\text { HBsAg+ve } \\
n(\%)\end{array}$ & $\begin{array}{l}\text { Children } \\
\text { anti-HBs+ve } \\
n(\%)\end{array}$ & $\begin{array}{l}\text { Total } H B s A g+v e \\
\text { or anti-HBs+ve } \\
n(\%)\end{array}$ \\
\hline $\begin{array}{l}\text { Father and mother both positive } \\
\text { Mother only positive } \\
\text { Father only positive } \\
\text { Father and mother both negative }\end{array}$ & $\begin{array}{r}452 \\
2697 \\
2979 \\
26173\end{array}$ & $\begin{array}{l}199(44 \cdot 0) \\
1035(38 \cdot 4) \\
536(18 \cdot 0) \\
2409(9 \cdot 2)\end{array}$ & $\begin{array}{r}17(3 \cdot 8) \\
129(4 \cdot 8) \\
173(5 \cdot 8) \\
1179(4 \cdot 5)\end{array}$ & $\begin{array}{r}216(47 \cdot 8) \\
1164(43 \cdot 2) \\
709(23 \cdot 8) \\
3588(13 \cdot 7)\end{array}$ \\
\hline Total & 32301 & $4179(12 \cdot 9)$ & $1498(4 \cdot 6)$ & $5677(17 \cdot 6)$ \\
\hline
\end{tabular}

the HBsAg carrier rate in infants born to HBsAg negative mothers fell from $15 \cdot 4 \%$ to $3.3 \%$ in 1 year olds and from $11 \cdot 6 \%$ to $2 \cdot 1 \%$ in 2 year olds, a statistically significant difference in each case $(p<0 \cdot 001){ }^{8}$ The results suggest that inappropriate use of needles and syringes is a major route of $\mathrm{HBV}$ transmission.

TRANSMISSION VIA TRANSFUSION OF BLOOD AND BLOOD PRODUCTS

Since 1973, blood donors and blood products have been screened for HBsAg. The standard method at present is an EIA kit incorporating national quality control reference panels. After the introduction of $\mathrm{HBsAg}$ screening, the incidence of post-transfusion hepatitis $B$ fell considerably but has not yet been reduced to zero. In one study, for example, all $70 \mathrm{HBV}$ negative transfusion recipients were given $\mathrm{HBsAg}$ negative blood (tested by RIA), yet one patient still developed acute hepatitis $B$ three months later. ${ }^{9}$ Screening for anti-HBc would be of no practical value in preventing transmission of HBV because around 55-65\% of the general population in China are anti-HBc positive.

\section{TRANSMISSION BETWEEN SPOUSES}

An interesting study has been carried out to determine the impact of sexual contact on HBV infection among newly married couples. ${ }^{10}$ Fifty seven couples comprising one $\mathrm{HBsAg} /$ anti-HBc positive partner and one HBV marker negative (that is, susceptible) partner were included in the study. A further 61 couples, all of whom were negative for $\mathrm{HBV}$ markers, were enrolled as a control group. The observation period ranged from 24 to 31 months (average 27 months). At the end of the study, the HBV infection rate was $62 \cdot 6 \%$ among previously negative partners in the study group, with $14 \%$ remaining $\mathrm{HBsAg}$ positive. In contrast, the incidence of HBV infection in the control group was $16 \%$, with an HBsAg positivity rate of only $1 \cdot 6 \%$. The RR between these two groups was $\mathbf{8 \cdot 6}$ for HBsAg

TABLE IV Relation between $\mathrm{HBs} A g$ status of parents and that of their children in urban and rural areas ${ }^{6}$

\begin{tabular}{|c|c|c|c|c|c|}
\hline \multirow[b]{2}{*}{$\begin{array}{l}\text { HBs } A g \text { status } \\
\text { of parents }\end{array}$} & \multicolumn{2}{|l|}{ Urban } & \multicolumn{2}{|l|}{ Rural } & \multirow[b]{2}{*}{ p Value } \\
\hline & $\begin{array}{l}\text { No of } \\
\text { families } \\
\text { tested }\end{array}$ & $\begin{array}{l}\text { Families with } \\
\text { HBsAg+ve } \\
\text { children } \\
n(\%)\end{array}$ & $\begin{array}{l}\text { No of } \\
\text { families } \\
\text { tested }\end{array}$ & $\begin{array}{l}\text { Families with } \\
\mathrm{HBs} A \mathrm{~g}+\mathrm{ve} \\
\text { children } \\
n(\%)\end{array}$ & \\
\hline $\begin{array}{l}\text { Father and mother both positive } \\
\text { Mother only positive } \\
\text { Father only positive } \\
\text { Father and mother both negative }\end{array}$ & $\begin{array}{r}24 \\
163 \\
162 \\
2161\end{array}$ & $\begin{array}{r}10(41 \cdot 7) \\
87(-53 \cdot 4) \\
42(25 \cdot 9) \\
360(16 \cdot 7)\end{array}$ & $\begin{array}{r}129 \\
839 \\
931 \\
7530\end{array}$ & $\begin{array}{r}97(75 \cdot 2) \\
505(60 \cdot 2) \\
400(43 \cdot 0) \\
2034(27 \cdot 0)\end{array}$ & $\begin{array}{l}<0.001 \\
>0.05 \\
<0.001 \\
<0.001\end{array}$ \\
\hline Total & 2510 & $499(19 \cdot 9)$ & 9429 & $3036(32 \cdot 1)$ & $<0.001$ \\
\hline
\end{tabular}

and $3 \cdot 1$ for $\mathrm{HBV}$ infection, a statistically significant difference $(\mathrm{p}<0 \cdot 01) .10$

HBV INFECTION AMONG MEDICAL PERSONNEL Medical personnel are considered to represent a high risk population for HBV infection. However, a number of surveys have shown that the prevalence of $\mathrm{HBsAg}$ is no higher among such people than among the general population, although more are anti-HBs positive. During a four year study of 667 medical and nursing students (two years in school and two years after graduation), the $\mathrm{HBV}$ infection rate increased from $3 \cdot 8 \%$ at baseline to $11 \cdot 2 \%$ at the end of the study and the $\mathrm{HBsAg}$ positivity rate increased from $0.5 \%$ to $4.0 \% .{ }^{11}$ The HBsAg positivity rate among those who had experienced medical injuries (for example, needle sticks) or undergone medical procedures (for example, intravenous infusion, acupuncture, and tooth extraction) was higher than in those without such a history and was directly related to the number of exposures. ${ }^{11}$

\section{Strategy for prevention of $\mathrm{HBV}$ infection in China}

The basic strategy for the prevention of HBV infection in China is the introduction of HBV vaccination into the national Expanded Programme on Immunisation (EPI), and vaccination of certain high risk groups. In addition, strict sterilisation of all medical instruments, syringes, and needles (including acupuncture needles), together with screening of blood donors and blood products and control of iatrogenic infections are all important preventive measures. At present, there is no general policy for vaccination of adolescents or adults.

VACCINATION OF NEWBORNS

All newborns and young children are to be vaccinated against hepatitis $B$, whether their mothers are $\mathrm{HBsAg}$ positive or negative. Because less than $20 \%$ of all chronic HBV infection is reported to result from perinatal infection and only $32 \%$ of carriers born to HBsAg positive mothers are $\mathrm{HBsAg}$ positive due to the combined impact of perinatal and horizontal routes of infection, 45 vaccination only of those infants born to $\mathrm{HBsAg}$ positive mothers is insufficient for complete control of HBV infection. ${ }^{12}$ A trial hepatitis $B$ vaccination programme was carried out in the southern district of Shanghai city, with a population of approximately 780000 and an annual birth rate of around $10000 . .^{13}$ Between 1986 and 1990 , more than $95 \%$ of newborns in this area were vaccinated with plasma derived $\mathrm{HBsAg}$ vaccine. The $\mathrm{HBsAg}$ carrier rate among young children fell from $9 \cdot 4 \%$ before vaccination to $0.9 \%$ after four years, with a protection rate of $89.6 \% .^{13}$ During the period 1988 to 1990 , a nationwide hepatitis $B$ vaccination programme was introduced, and was made possible by sufficient supplies of domestically produced plasma derived or recombinant hepatitis B 
vaccine. ${ }^{14} 15$ Anti-HBs responses to the vaccine are shown in the paper by Professor Yao Jilu (see pages S37-S38).

\section{VACCINATION OF HIGH RISK GROUPS}

For high risk groups, such as medical or laboratory workers, blood centre and blood products workers, and newly married people with HBsAg positive spouses, a full course of hepatitis $B$ vaccine should be given. There are convincing data for the efficacy of hepatitis B vaccine in protecting newly employed medical personnel. ${ }^{16}$ Among $220 \mathrm{HBV}$ negative student nurses given three doses of hepatitis $\mathrm{B}$ vaccine, not one developed $\mathrm{HBV}$ infection or became HBsAg positive during the 24 month follow up period. In contrast, two of 234 non-vaccinated students became positive for $\mathrm{HBsAg}$ and anti-HBc (one experiencing acute hepatitis) and nine became anti-HBs or anti$\mathrm{HBc}$ positive, or both, giving a total infection rate of $5 \cdot 8 \%{ }^{16}$ As yet, there is no evidence that vaccination has had much impact for the newly married.

\section{Conclusion}

Both perinatal and horizontal transmission play important parts in the transmission and persistence of $\mathrm{HBV}$ infection. In China, horizontal transmission seems to be more important. Vaccination for all neonates, young children, and high risk population groups is therefore the fundamental strategy for hepatitis
B prevention. Prevention of iatrogenic infection is also essential.

$1 \mathrm{Qu}$ ZY. An epidemiological study on the distribution of HBsAg and anti-HBs in China. Chinese $\mathcal{f}$ Microbiol Immunol 1986; 6: S20-40.

$2 \mathrm{Hu} Z \mathrm{ZH}, \mathrm{Qu} \mathrm{ZY}$, Jing Q, et al. The overall infection rate of HBV in Chinese general population by sampling investi-

3 Liu CB, Xu ZY, Cao HL, et al. Sero-epidemiology of HBV infection in four provinces in China. Chinese $\mathcal{F}$ Virol 1991; 7: S8-14

$4 \mathrm{Xi}$ LF, Xu ZY, Shen YD, et al. The horizontal and perinatal transmission of hepatitis B virus infection. Chinese $\mathcal{F}$ Virol 1991; 7: S21-4.

$5 \mathrm{Xu}$ ZY. Study on the strategy for the vaccination prevention of HBV in Shanghai. Shanghai $₹$ Preventive Med 1989; 1: $16-24$

6 Jing Q. Some characteristics of the intrafamily infection of HBsAg in China. Chinese 7 Microbiol Immunol 1986; 6: S41-8.

7 Liu LH, Wang HX, Yin DC, et al. Prevalence and incidence of hepatitis $B$ virus infection in 3-5 years old kindergarten children. $\mathcal{F}$ Virol 1991; 7: S25-9.

$8 \mathrm{Ma} \mathrm{JC}$, Sun TD, Xie YF, et al. A study on the relationship between disinfection of syringes, acupuncture needles, transfusion sets and $\mathrm{HBV}$ infection in children under 2 years. Chinese f Virol 1991; 7: S30-4.

9 Wang SP, Zheng RJ, Si SX, et al. A study of post-transfusion hepatitis. Chinese f Virol 1991; 7: S45-7.

10 Fang XS, Li LC, An K, et al. HBV infection among newly married couples. Chinese f Virol 1991; 7: S35-7.

11 Sun YD, MA XW, Xie BG, et al. A cohort study of hepatitis $B$ virus infection among medical and nursing students. tis B virus infection among medical

$12 \mathrm{Xu} \mathrm{ZY,} \mathrm{Liu} \mathrm{CB,} \mathrm{Yan} \mathrm{TJ,} \mathrm{et} \mathrm{al.} \mathrm{Evaluation} \mathrm{of} \mathrm{effectiveness} \mathrm{of}$ large-scale hepatitis B vaccination in neonates. Chinese $f$ Virol 1991; 7: S48-52.

$13 \mathrm{Xu} \mathrm{ZY}$. Long-term observation of $\mathrm{HB}$ vaccination in Shanghai Southern District. Shanghai $f$ Preventive Med 1990; 2: 24-6

14 Chen WF, Guo ZH, Zhong YJ, et al. The persistence of immunity of $\mathrm{HB}$ vaccination in newborn infants. Chinese $f$ Epidemiol 1994; 15: 76-9.

15 Tao WL. Persistence of immunity of HB vaccination. Chinese f Exp Clin Virol 1995; 9: 97-9.

16 Yao GB, Xu DL, Xia LR, et al. Study on the status of hepatitis $B$ infection and the efficacy of $H B$ vaccine among hepatitis B infection and the efficacy of HB vaccine among 9: $216-20$. 